\title{
Incidence of leaf rot disease in relation to root (wilt) in young coconut palms and fungi in lamina and petiole lesions
}

\author{
N. Srinivasan ${ }^{1}$
}

\begin{abstract}
Coconut leaf rot in association with root (wilt) is widespread in southern districts of Kerala, India. The disease complex has spread to northern districts of the state and also adjacent districts in Tamil Nadu. Where as the root (wilt) is a systemic infection (due to phytoplasma) the leaf rot is a foliar syndrome due to fungi (Colletotrichum gloeosporioides, Exserohilum rostratum, Fusarium spp.). Occurrence of leaf rot has been related to the incidence of root (wilt) and its appearance in young palms remained a matter of contention as to which disease precedes the other. Leaf rot lesions do occur on leaf petiole/mid-vein/mid-rib even as the disease lesions are known to be common on lamina (spindles). Investigations brought out that in majority of leaf rot affected young palms (2-5 years old) the flaccidity symptom of root (wilt) could be also discerned. In lesser number of affected palms, the other symptoms of root (wilt), yellowing and marginal necrosis, were also visible. As such, in $88.5 \%$ of leaf rot affected young palms one or the other symptom of root (wilt) has been recorded irrespective of season. $C$. gloeosporioides, E. rostratum and other fungi were found both in lamina and petiole lesions in different months. C. gloeosporioides was detected from petiole and lamina tissues in all the months, followed by E. rostratum, Fusarium spp. etc. $C$. gloeosporioides was isolated from these parts in more numbers and consistently during January-December. E. rostratum appeared erratically. Aggressiveness of $C$. gloeosporioides during months of wet season was confirmed. Fusarium spp. was isolated predominantly from these parts in dry months (January-May). Knowledge on occurrence of leaf rot in young palms in relation to root (wilt) and dynamics of leaf rot pathogens in leaf parts among months/seasons of year (in inoculums build-up, spread and dissemination) are important in the context of integrated management of root (wilt)-leaf rot complex.
\end{abstract}

Key words: Coconut, root (wilt) disease, leaf rot disease, phytoplasma, fungi and India.

\footnotetext{
${ }^{1}$ Central Plantation Crops Research Institute, Regional Station, Kayangulam, Krishnapuram - 690533 , Kerala, India. Email: srinivasannarayanasamy@yahoo.com/cpcrikgm@vsnl.com
} 


\section{Introduction}

Leaf rot disease of coconut is common and widespread in root (wilt) endemic southern districts of Kerala, India and in recent years the disease has spread to northern districts of the state and also certain districts of Tamil Nadu. Root (wilt) is a slow, debilitating malady. Superimposition of leaf rot in root (wilt) affected palm disfigures the crown and brings about rapid deterioration leading to yield losses. Earlier studies brought out general occurrence of leaf rot in relation to root (wilt) and leaf rot symptoms, which are appearance of lesions especially in emerging spindle leaves, fungal complex nature of etiology etc. (Menon and Nair, 1951; Srinivasan, 2002a,b). Interrelation of leaf rot with root (wilt) has been established and general vulnerability of palms with root (wilt) symptoms elucidated. The association of various fungi, their population fluctuations in relation to weather was studied through isolations made from lamina lesions of leaf rot affected palms. Collection of information on leaf rot incidence in relation to pattern of root (wilt) symptom expression, especially on young palms was felt necessary. Leaf rot lesions have been observed commonly in parts such as petiole, mid-veins etc. of leaves, besides the common rotting of lamina tissues in affected palms. Hence, it was desired to generate more information on the incidence pattern of leaf rot especially in young palms in the field and also incidence of fungi in parts such as petiole, midveins etc. in comparison with lamina.

\section{Materials and methods}

The number of leaf rot affected palms bearing the root (wilt) symptoms (flaccidity alone or flaccidity with yellowing or flaccidity with yellowing and marginal necrosis) or otherwise were recorded (George and Radha, 1973; Solomon et al., 1999; Srinivasan and Gunasekaran, 2000b). For this, the naturally leaf rot affected young palms (2-5 years old) in gardens were assessed quarter wise, April to March (2002-03). In each quarter, 50 leaf rot affected palms were randomly examined for any of the symptoms of root (wilt) or otherwise. The details on incidence of leaf rot with flaccidity alone, flaccidity with yellowing, flaccidity with yellowing and marginal necrosis, root (wilt) free if any, were recorded and the data consolidated for comparison.

Experiments were also conducted to assess the fungal associations in leaf rot lesions developed in lamina and petiole parts. In each experiment monthly sampling (April to March, 2002-2003) of infected palms were made. In every month samples of lamina (spindle) and petiole/mid-vein (young leaves) from five palms, in each category, were obtained. Two hundred and fifty infected pieces of each category per month were inoculated onto potato-dextrose agar medium and fungi isolated as described (Srinivasan and Gunasekaran, 1996).

\section{Results and discussion}

Leaf rot affected young coconut palms were identified based on the disease symptoms in spindle, inner whorl, middle whorl and outer whorl of the crown. In each affected palm, expression of any of the symptoms of root (wilt) (individually or in combinations) was examined. In this study, a total of 200 palms were examined in such a manner. The frequency of expression of root (wilt) symptoms in leaf rot affected palms is presented in Table 1. Among the sampled palms, 177 palms (88.5\%) exhibited root (wilt) symptoms (flaccidity alone or flaccidity with other symptoms, as the case may be). In majority of these root (wilt) plus leaf rot affected palms (62\%), however, flaccidity symptom was discerned. Comparatively lesser number of leaf rot affected young palms with the root (wilt) symptoms of flaccidity + yellowing $(16.50 \%)$ or flaccidity + yellowing + marginal necrosis of leaf lets $(10.0 \%)$ were recorded. The frequency of leaf rot incidence was less in palms free from root (wilt) symptoms. A similarity in frequency of palms expressing status of root (wilt) symptom(s) in leaf rot affected cases among quarters of observation was also evident - 54$70 \%$ leaf rot affected palms with flaccidity; $10-$ $24 \%$ with flaccidity + yellowing; 3-8\% with flaccidity + yellowing + marginal necrosis. As such in majority of the sampled leaf rot affected young palms $(62 \%)$ the principal symptom of 
root (wilt) - flaccidity could be pointed out. In $26.50 \%$ of leaf rot affected palms the symptoms of root (wilt) - flaccidity + yellowing or flaccidity + yellowing + marginal necrosis, as the case may be, occurred. This observation gains more importance as earlier studies established interrelation of leaf rot with root (wilt) and young palms affected with root (wilt) became more vulnerable to leaf rot (CCRS, 1970; Srinivasan, 1991). In a population of palms, leaf rot incidence occurred in root (wilt) free/apparently healthy palms in fewer cases; such palms also developed the root (wilt) symptoms subsequently (CCRS, 1971; Radha and Lal, 1968).

Root (wilt) is a systemic disease wherein the expression of disease symptom is a slow process. The flaccidity symptom is expressed first and the other symptoms of yellowing and marginal necrosis are the result of protracted effect of the disease due to host - parasite (phytoplasma) interaction. The flaccidity symptom commonly seen in leaf rot affected palms in the study corroborates this view and thus leaf rot had contracted preferably the root (wilt) affected palms. In certain leaf rot affected palms where yellowing and marginal necrosis seen could be the cases of relatively advanced state of root (wilt) infection. The possibility of leaf rot contracting the root (wilt) palms in the latent stage of systemic infection is also seen (Radha and Lal, 1968). Systemically infected crop plants (due to virus) succumbing to fungal pathogens have been reported elsewhere and such a situation in root (wilt) - leaf rot complex is a unique phenomenon of phytoplasma - fungal combination (Srinivasan and Gunasekaran, 1999). The leaf rot in young palms (Fig. 1-6) is therefore interrelated to the incidence of root (wilt). Extensive rotting of tissues in emerging spindles of the typical leaf rot affected young palms is observed in the field. Mild-restricted lesions could be discerned occasionally in leaves of apparently root (wilt) free palms and even in young - emerging, un-split leaves. Vulnerability of young palms with root (wilt) and the process of disease development are of importance.

Incidence of C.gloeosporioides, E. rostratum and other fungi of leaf rot were associated with petiole and lamina lesions of leaf rot affected young palms (Fig. 7-8) during different months of sampling (Table 2). C.gloeosporioides was detected in all months irrespective of part sampled, but its incidence seen commonly during June - December. Association of E.rostratum was also recorded but erratically. Incidence of other fungi (particularly Fusarium spp.) was common in the months of January - May (dry period). Fungal recovery from petiole/mid-veins and lamina pieces was found by and large in a similar trend as the mean recovery stood at $57.0 \%$ and $59.7 \%$ respectively (data not shown). C.gloeosporioides was isolated from more number of petiole (60-120) and lamina (88-160) pieces in the months of June - December followed by E.rostratum. In the months of January - May, the incidence of other fungi (Fusarium spp.) was predominantly observed both in petiole and lamina pieces. From the data it is evidenced that incidence of C.gloeosporioides in both petiole and lamina parts is higher (than E.rostratum) during wet season and its population subdued in dry months when other fungi like Fusarium spp. dominate. The aggressiveness of C.gloeosporioides during wet months leading to infections of both petiole and lamina parts is evident. Activity of pathogens depending upon season of the year and infection of different parts may be of importance in the disease perpetuation.

Earlier studies based mainly on isolations from lamina samples, established fungal complex nature of leaf rot and C.gloeosporioides as the principal pathogen during monsoon months (Srinivasan and Gunasekaran, 1996, 2000a). The present study corroborated the earlier results and also established association of leaf rot fungi with 

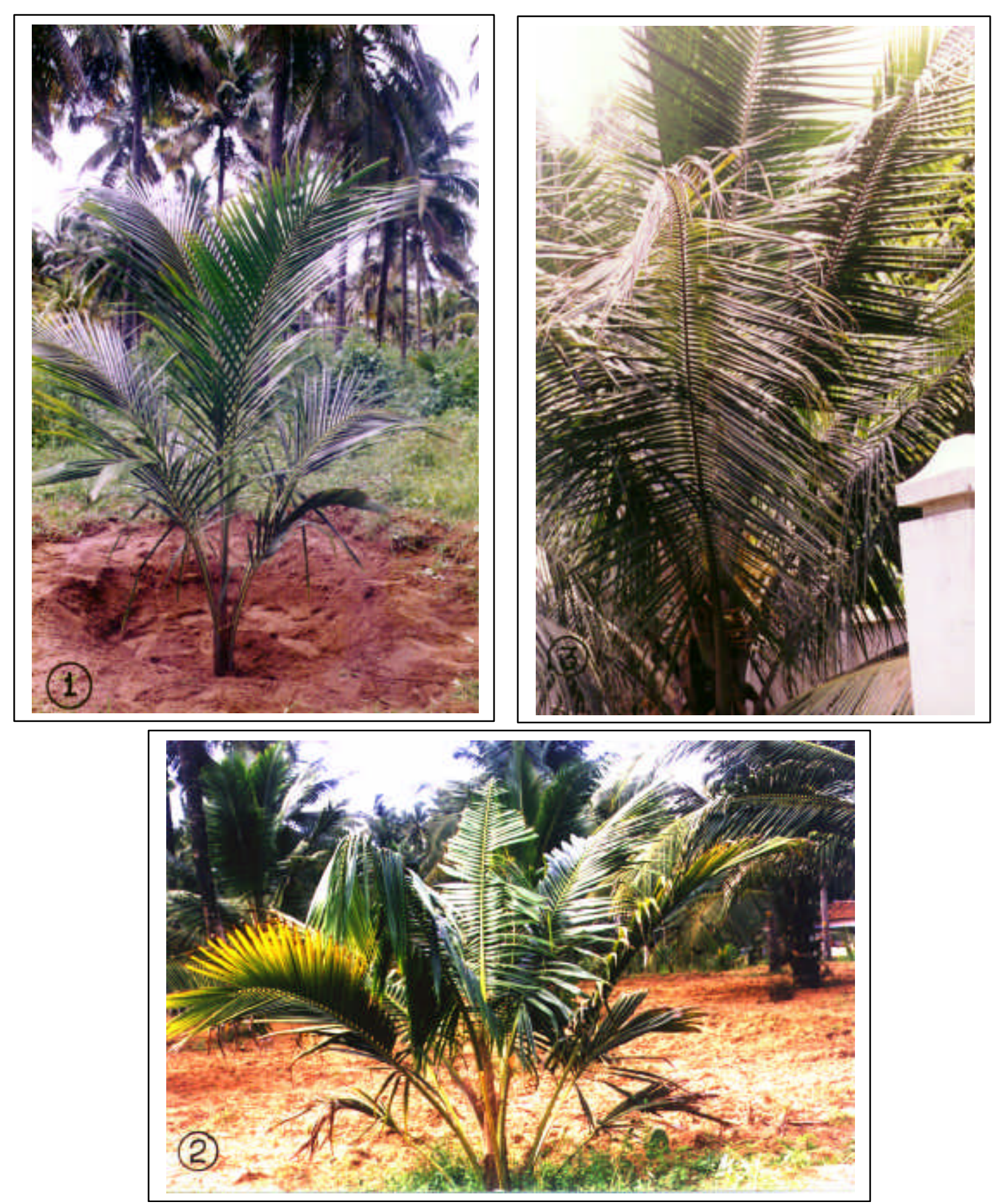

Fig. 1-3. Root (wilt) affected young coconut palms - in early (1), middle (2) and advanced (3) stage expression of disease symptoms 


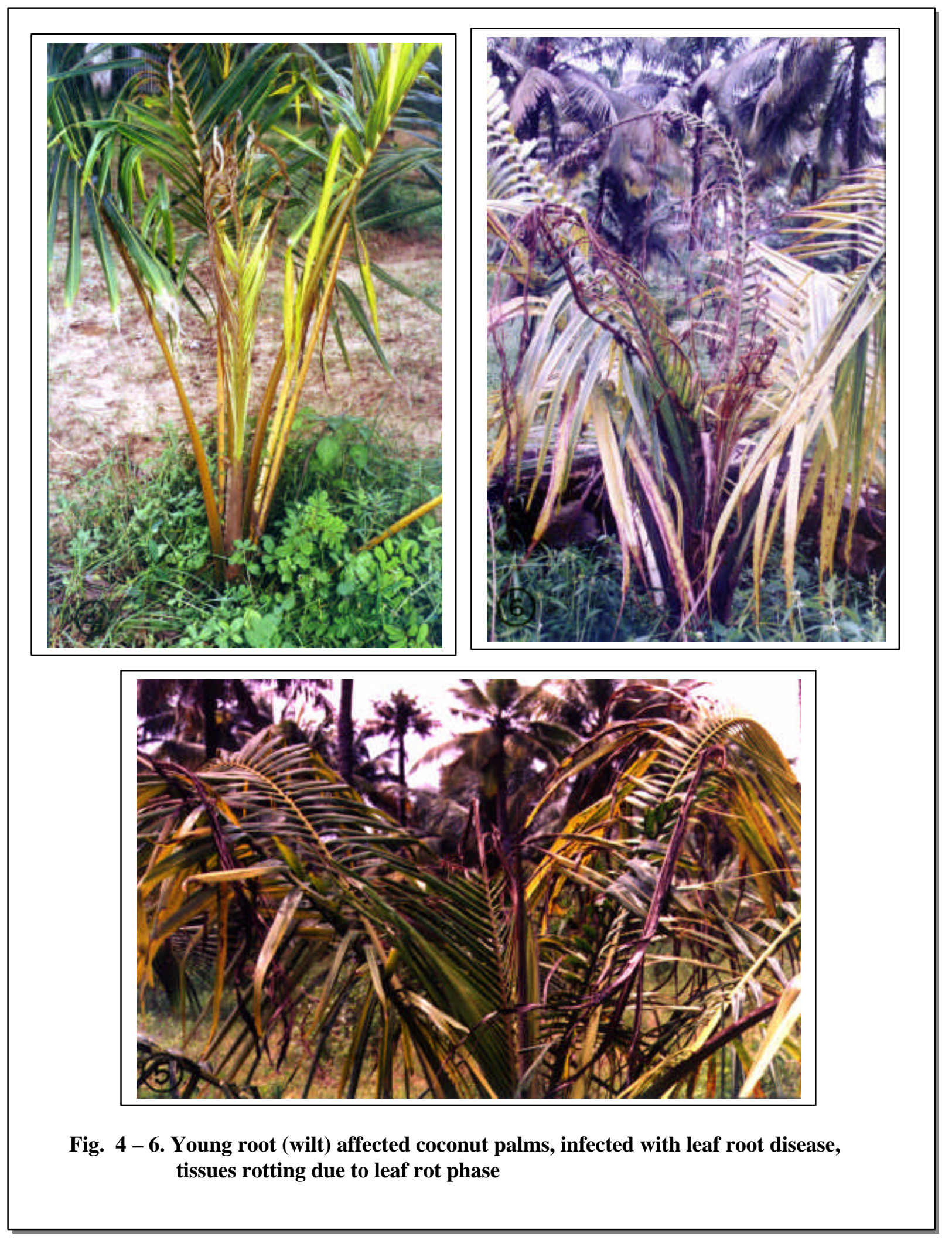




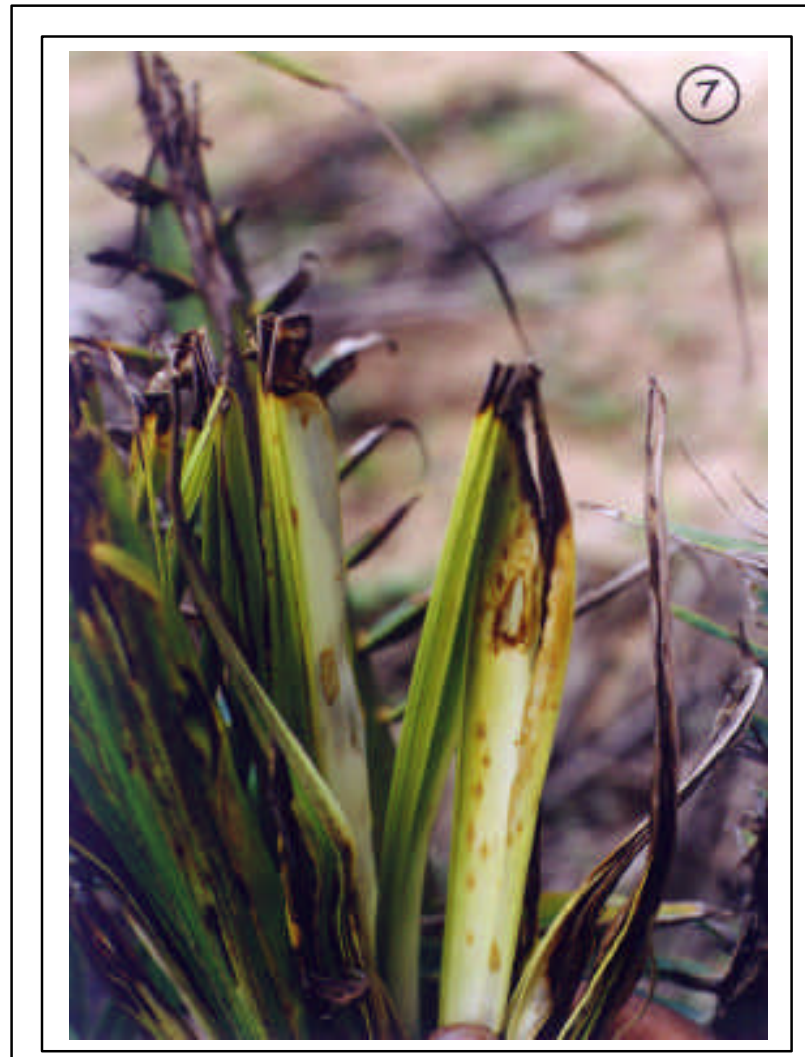

Fig. 7. Leaf rot disease lesions as expanding on lamina part of affected leaf

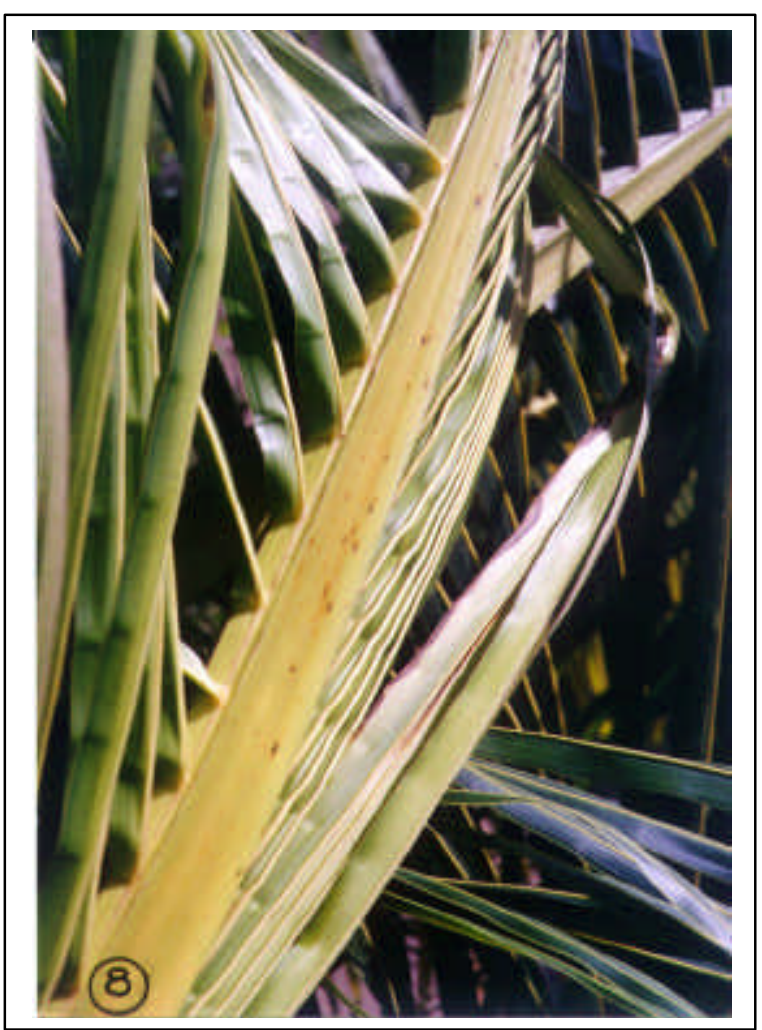

Fig. 8. Leaf rot disease lesions on petiole/midvein part of affected leaf

Table 1. Frequency of expression of root (wilt) symptoms in leaf rot affected young coconut palms*

\begin{tabular}{|c|c|c|c|c|}
\hline \multirow[b]{2}{*}{$\begin{array}{l}\text { Observation period } \\
\quad(2002-2003)\end{array}$} & \multicolumn{3}{|c|}{ No. of leaf rot palms with root (wilt) symptoms } & \multirow[b]{2}{*}{$\begin{array}{l}\text { No. of palms in } \\
\text { others/doubtful cases }\end{array}$} \\
\hline & Flaccidity & $\begin{array}{c}\text { Flaccidity } \\
+ \\
\text { Yellowing }\end{array}$ & $\begin{array}{c}\text { Flaccidity } \\
+ \\
\text { Yellowing } \\
+ \\
\text { Marginal necrosis }\end{array}$ & \\
\hline $\begin{array}{l}2002 \\
\text { April - June } \\
\text { July-September }\end{array}$ & $\begin{array}{l}30(60 \%) \\
27(54 \%)\end{array}$ & $\begin{array}{l}10(20 \%) \\
12(24 \%)\end{array}$ & $\begin{array}{l}05(10 \%) \\
04(08 \%)\end{array}$ & $\begin{array}{l}05(10 \%) \\
07(14 \%)\end{array}$ \\
\hline $\begin{array}{l}\text { October - December } \\
2003\end{array}$ & $32(64 \%)$ & $06(12 \%)$ & $08(16 \%)$ & $04(08 \%)$ \\
\hline $\begin{array}{l}\text { January - March } \\
\text { Total palms }\end{array}$ & $\begin{array}{c}35(70 \%) \\
124\end{array}$ & $\begin{array}{c}05(10 \%) \\
33\end{array}$ & $\begin{array}{c}03(06 \%) \\
20\end{array}$ & $\begin{array}{c}07(14 \%) \\
23\end{array}$ \\
\hline $\begin{array}{l}\text { Mean palms } \\
\text { (For period) }\end{array}$ & 31.00 & 08.25 & 05.00 & 05.75 \\
\hline $\begin{array}{l}\text { Per cent palms } \\
\text { (Total/Mean) }\end{array}$ & 62.00 & 16.50 & 10.00 & 11.50 \\
\hline
\end{tabular}

*out of 50 palms in each period 
Table 2. Fungi isolated from petiole/mid-vein and lamina lesions of leaf rot affected young coconut palms*

\begin{tabular}{|c|c|c|c|c|c|c|}
\hline \multirow{2}{*}{$\begin{array}{l}\text { Month } \\
(2002- \\
2003)\end{array}$} & \multicolumn{3}{|c|}{$\begin{array}{c}\text { No. of palms yielding fungi - from petiole } \\
\text { lesions }\end{array}$} & \multicolumn{3}{|c|}{ No. of palms yielding fungi - from lamina lesions } \\
\hline & $\mathrm{Cg}$ & $\mathrm{Er}$ & Other fungi** & $\mathrm{Cg}$ & $\mathrm{Er}$ & Other fungi** \\
\hline 2002 & & & & & & \\
\hline April & 1 & 0 & 5 & 2 & 1 & 5 \\
\hline May & 2 & 2 & 4 & 2 & 1 & 5 \\
\hline June & 5 & 1 & 4 & 5 & 1 & 3 \\
\hline July & 5 & 3 & 5 & 5 & 2 & 4 \\
\hline August & 5 & 2 & 4 & 4 & 2 & 2 \\
\hline September & 4 & 4 & 3 & 5 & 3 & 1 \\
\hline October & 5 & 3 & 5 & 4 & 1 & 5 \\
\hline November & 4 & 2 & 1 & 5 & 4 & 3 \\
\hline $\begin{array}{l}\text { December } \\
2003\end{array}$ & 5 & 4 & 4 & 5 & 3 & 2 \\
\hline January & 3 & 2 & 4 & 4 & 2 & 5 \\
\hline February & 1 & 0 & 5 & 1 & 1 & 4 \\
\hline March & 1 & 1 & 4 & 1 & 0 & 4 \\
\hline Mean & 3.4 & 2.0 & 4.0 & 3.6 & 1.8 & 3.6 \\
\hline $\begin{array}{c}\text { C.D. } \\
(\mathrm{P}=0.05)\end{array}$ & \multicolumn{3}{|c|}{1.1} & \multicolumn{3}{|c|}{1.3} \\
\hline
\end{tabular}

*Out of 5 palms/Month/Category; $\mathrm{Cg}=$ Colletotrichum gloeosporioides $; \mathrm{Er}=$ Exserohilum rostratum

**Other fungi - Gliocladium vermoeseni, Fusarium spp., Thielaviopsis paradoxa, Rhizoctonia solani, Cylindrocladium scoparium, Mortierella elongata

petiole/mid-vein lesions of leaf rot. Predominance of Fusarium spp. in dry months both in lamina and petiole parts also have been found. In leaf rot affected palms, the disease lesions were commonly found in lamina tissues and also encountered in petiole/mid-vein parts, the disease symptoms were also reproduced (Srinivasan and Gunasekaran, 2000a). In this context, it is important to note that in leaf rot infected palms under natural conditions the disease lesions could be seen in petioles of recently emerged young leaves. In such palms, an infection in subsequently emerged spindle leaf is common. It is possible that the inoculums present right in the petiole lesion, which is in very close proximity to the emerging spindle of a given time, would effectively infect the spindle tissues. Unlike the extensive rotting of lamina tissues due to the pathogens, the disease lesions established in petiole parts remained generally restricted. This may be due to hardness of petiole tissues as compared to lamina tissues, which might favor rapid expansion of lesions (Srinivasan and Gunasekaran, 1992). However, these lesions in petiole and other parts (Srinivasan and Gunasekaran, 1999) also make the palm weaker as they render affected leaf or leaflets break. The association and viability of pathogens in petiole/mid-vein parts (in addition to lamina tissues) also lead to the inoculum generation, spread and dissemination (Srinivasan, 2002a; Srinivasan and Gunasekaran, 2000a, b). The results gained on incidence pattern of leaf rot in young palms and associations of leaf rot pathogens with petiole and lamina lesions, as inoculum source would be useful (Srinivasan, 2003, 2004; Srinivasan and Gunasekaran, 2003 ) in the leaf rot management measures. 


\section{References}

CCRS, 1970. Annual Report 1968. Central Coconut Research Station (CPCRI) Kayangulam, India, 87 pp.

CCRS, 1971. Annual Report 1966. Central Coconut Research Station (CPCRI) Kayangulam, India, 64 pp.

George, M. V. and Radha, K. 1973. Computation of disease index of root (wilt) disease of coconut. Indian Agric. 43: 366-370.

Menon, K.P.V. and Nair, U.K. 1951. Scheme for the investigation of the root and leaf diseases of the coconut palms in south India. Consolidated final report of the work done from $8^{\text {th }}$ March 1937 to 31st March 1948. Indian Cocon. J. 5(1): 5 - 19.

Radha, K. and Lal, S.B. 1968. Some observations on the occurrence of leaf rot disease of coconut and associated factors. Paper Third Sess. FAO Tech. Work. Party, Cocon. Prod. Prot. and Proc., Jog Jakarta, pp. 1 - 5.

Solomon, J.J., Nair, C.P.R., Srinivasan, N., Gunasekaran, M. and Sasikala, M. 1999. Coconut root wilt - the malady and remedy. J. Plantn. Crops 27 (2): 71 - 92.

Srinivasan, N. 1991. Occurrence of coconut leaf rot in relation to root (wilt) disease. Indian Cocon. J. 21 (10): 14 - 18.

Srinivasan, N. 2002a. Coconut leaf rot complex and perspectives for the disease control Status report. Indian Cocon. J. 32 (9): 2-9 (Article reproduced in The Planter $\mathbf{7 8}$ (913): 203-216).

Srinivasan, N. 2002b. Current status of leaf rot and its management in root (wilt) affected coconut palms. In: Abstracts of Research Papers Presented in $54^{\text {th }}$ Annual Meeting and National Symposium on Crop Protection and WTO $-A n$ Indian
Perspective. Central Plantation Crops Research Institute, Kasaragod, January 22 - 25, 2002, p. 48 (Abstract appeared in Indian Phytopathology 55 (3): 364-365.

Srinivasan, N. 2003. Coconut root (wilt) - leaf rot disease and their integrated management, pp. 72-76. In: Souvenir, National Symposium on Coconut and Coconut Products in Health and Disease, 19-20 September, 2003, Department of Biochemistry, University of Kerala, Thiruvananthapuram, India.

Srinivasan, N. 2004. Coconut root (wilt) disease and its management. Indian Fmg. 54 (1): 3$4,8-9,11$.

Srinivasan, N. and Gunasekaran, M. 1992. An appraisal of symptom expression in coconut due to leaf rot disease. Indian Cocon. J. 23 (7): 2 - 6.

Srinivasan, N. and Gunasekaran, M. 1996. Incidence of fungal species associated with leaf rot disease of coconut palms in relation to weather and the stage of lesion development. Ann. App. Biol. 129 (3): 433 - 449.

Srinivasan, N. and Gunasekaran, M. 1999. Coconut leaf rot disease complex - A review. Cord 15 (1): 33 - 65.

Srinivasan, N. and Gunasekaran, M. 2000a. Etiology and recurrence of coconut leaf rot with special reference to seedlings, pp. 400-403. In: Recent Advances in Plantation Crops Research, N. Muraleedharan and R. Raj Kumar (Eds.). Paper presented at the Thirteenth Plantation Crops Symposium (PLACROSYM X111, Coimbatore, December 16 - 18, 1998), Allied Publishers Ltd., New Delhi, India.

Srinivasan, N. and Gunasekaran, M. 2000b. Leaf rot disease of coconut, Rohini Iyer (Ed), Technical Bulletin No. 38, Central 
Plantation Crops Research Institute, Kasaragod, India, 14 pp.

Srinivasan, N. and Gunasekaran, M. 2003. Curative and prophylactic control of fungal leaf rot complex in root (wilt) affected coconut palms in India. Cord 19(1): 17-26. 
